\title{
Female Commissioner and Earnings Quality: a Moderating Role of President Director's Ability
}

\author{
VITA ELISA FITRIANA* \\ Faculty of Business, Universitas Presiden, Indonesia \\ SLAMET SUGIRI
}

Faculty of Economics and Business, Universitas Gadjah Mada, Indonesia

\begin{abstract}
Prior studies show that the effect on earnings quality of female commissioner in many aspects of the company is inconsistent. Furthermore, previous studies focus only on the company with one-tier board governance. These two facts motivate us to investigate the role of female commissioner in improving earnings quality in the different background, especially in company with two-tier board governance. We also examine the role of president director's ability to solve the inconsistent effect of a female commissioner. We exert a sample of 707 manufacturing companies listed in Indonesia Stock Exchange from 2011 to 2015. By using multiple regression analysis, we do not find that female commissioner, as well as president director's ability, each positively affects earnings quality. However, we find positively significant results when these two variables interact. The finding that the interaction between the two variables is significant means that president director strengthens female commissioner in improving earnings quality.
\end{abstract}

Keywords: female commissioner, managerial ability, earnings quality, Corporate Governance

Intisari: Penelitian terdahulu menunjukkan ketidakkonsistenan pengaruh direktur wanita terhadap kualitas laba. Penelitian-penelitian terdahulu juga hanya berfokus pada perusahaan dengan tata kelola berupa one-tier board. Kedua argumen tersebut menjadi motivasi penelitian ini untuk menguji peran direktur wanita dalam latar belakang yang berbeda, khususnya perusahaan dengan tata kelola berupa two-tier board. Selanjutnya, penelitian ini menguji pengaruh kecakapan presiden direktur untuk menjelaskan ketidakkonsitenan peran direktur wanita tersebut. Kami menggunakan sampel sebanyak 707 perusahaan manufaktur yang terdaftar dalam Bursa Efek Indonesia selama periode 2011-2015. Berdasarkan analisis regresi linier banyak, kami tidak mendapati bukti empiris bahwa direktur wanita, sebagaimana presiden direktur, secara sendiri-sendiri berpengaruh secara positif terhadap kualitas laba. Namun, penelitian ini mendapati bukti empiris bahwa interaksi antara kedua variabel tersebut signifikan. Hal itu dapat diinterpretasikan bahwa presiden direktur mendukung komisaris wanita untuk meningkatkan kualitas laba.

Kata kunci: komisioner wanita, kecakapan manajerial, kualitas laba ,tata kelola perusahaan

\footnotetext{
* Corresponding author: vita.lisa@president.ac.id
} 


\section{Introduction}

The purpose of this research is to examine the influence of female commissioner, president director's ability and earnings quality. Many studies have already been conducted regarding the role of a female commissioner in the company performance (Adams \& Ferreira, 2009), acquisitions (Levi et al., 2014; Dowling \& Aribi, 2013; Huang \& Kisgen, 2013), conservatism (Francis et al., 2005; Arun et al., 2015), market response (Farrell \& Hersch, 2005; Kang et al., 2010) and earnings quality (Srinidhi et al., 2011). However, those researches focus only on companies with one-tier board governance. Also, studies regarding the role of a female commissioner in the company remain inconsistent.

Gul et al. (2011) findings show that female commissioner tends to have a high level of transparency regarding the company's earnings information. That result is supported by Abbott et al. (2012) which state that the existence of female commissioner is related to lowering chance of company to re-submitting financial report. Also, Srinidhi et al. (2011) succeed in documenting a high level of women participation as the board of directors will result in obtaining higher earnings quality. However, Srinidhi et al. (2011) argue the results of that examination could not be generalized in the countries with legislation, regulation and cultural institution that is different from United States (US). That argument motivates us to conduct similar research in Indonesia context.

In previous research conducted by Firth et al. (2007), China is used as the sample due to its two tier-board governance is different from two-tier implemented in Europe Continental companies. Related to these arguments, Indonesia is worth to be the sample as it shares similar governance with China. Yet, a difference remains. In China, most owners of public companies are dominated by the government (Firth et al., 2007), whereas in Indonesia it is dominated by family ownership (Claessens et al., 2000). Claessens et al. (2000) state that since ownership company belongs to a family, there will be a strong separation between the controller parties and the owner parties compared to another type of governance. Therefore, Indonesia is assumed to be having stronger corporate governance than China. 
Specifically, Indonesia provides unique backgrounds for female commissioner research. Kusumastuti et al. (2007) state that the community system in Indonesia still assumes that men are more capable of taking the critical role or higher position in the company compared to women. Having the argument, it would be interesting to explore the role of female commissioner that exists in the top-level management.

Previous researchers document the inconsistent findings of the role of a female commissioner. Several types of research show that female commissioner has positive role (Adams \& Ferreira, 2009; Campbell \& Minguez-Vera, 2008; Farrel \& Hersch, 2005; Arun et al., 2015; Kang et al., 2010; Srinidhi et al., 2011), yet the other research show the negative role (Farrel \& Hersch, 2005; Hanani \& Aryani, 2011). Even a study shows that they do not have any significant relation at all (Kusumastuti et al., 2007; Mardiyati, 2016). In a broad term, these researches have a similarity. They do not consider the specific managerial aspect. In another side, Bertrand \& Schoar (2003) and Dejong \& Ling (2013) state that managerial characteristics become the factor in determining the company practice and decision. Thus, our study examines a president director's ability as the predictor of earnings quality.

In measuring earnings quality, discretionary estimation error model developed by Francis et al. (2005) is used for this research. Then, the female commissioner was measured by a percentage of female assigned in board commissioners (Farag \& Mallin, 2016). President director's ability was examined by the General Ability Index (GAI) developed by Custodio et al. (2013). A statistical tool in the form of a multiple linear regression is used to test the hypothesis.

According to our examination, we do not find evidence that female commissioner has positive impact on earnings quality. We do not find the effect on earnings quality of president director's ability either. However, we find that the interaction of female commissioner and president director's ability statistically, significantly affect earnings quality. This finding can be interpreted that president directors support the role of female commissioner in her efforts to improve earnings quality.

Our study contributes to a practical and theoretical perspective. On the practical side, this research can be used as a consideration for regulators. Taking into account 
Indonesia's unique characteristics, special regulations are required for the involvement of female members as a board of directors in the company. Also, most companies will employ high-ability presidential directors to organize them. Then, the existence of women directors will strengthen corporate governance, as they have a high tendency to increase supervision over management, including the president director. Therefore, the oversight by the female commissioner could encourage protection to investors, especially for a company in the weak shareholder protection country.

From a theoretical perspective, the inconsistent role of female commissioner could be explained by the president director's ability. Female commissioners tend to lose the oversight if they realize that the president director lacks capacity. On the other hand, when the president director has a high ability to run the company, female commissioners tend to strengthen her role as supervisor. She wants to ensure that the president director uses their ability to improve the performance of the company and enrich the investor as the owner instead of using their knowledge for their interest.

Despite its contribution, our study has some drawbacks that limit the conclusion. Firstly, the number of female commissioner in the company in manufacturing industries is relatively small. Secondly, the measurement of female commissioners does not consider a specific position of female commissioner in the board of commissioner. Thirdly, using the general ability index (GAI) in evaluating president director's ability decreases the accuracy because this measurement could not cover the working experience in different industries. Fourth, the GAI is focused only on the ability of president director, as for president director has a low tendency to directly conduct accounting discretion. Lastly, our study uses only a cross-sectional analysis to identify the influence of the president director ability towards earnings quality. Aside from that, there would be a possibility to examine the impact if the observation held in the form of a time-series method.

We organize our paper as follows. On the next part, we will discuss the hypothesis development alongside with literature review. After that we will elaborate research method consisting of sample selection and variables measurement. The 
statistical result will be discussed afterwards and followed by conclusion, limitation and suggestion for the future research.

\section{Theoretical Framework and Hypothesis Development}

\subsection{Agency Theory}

Many types of studies related to corporate governance underlie their argument with agency concepts (John \& Senbet, 1998; Bushman \& Smith, 2001; Upadhyay et al., 2014). The central idea of agency theory developed by Jensen \& Meckling (1976) states that contractual relations exist between principals and agents. Agents are parties that are employed by principals to work for the interest of principals by obtaining delegation of authority for the decision-making process. However, conflict of interests between principals and agents may implicate the rise of supervision cost to control the agents. It happens since their work is to follow the principals' interest.

Corporate governance is regarded as an exact mechanism to facilitate the stakeholder's interest in conducting supervision towards the internal side of company and management (John \& Senbet, 1998; Upadhyay et al., 2014). John \& Senbet (1998) view the role of supervision conducted by director become an essential component for governance since the shareholders have a limitation in supervising and controlling. In other words, corporate governance serves as a media to ensure the task of manager in conducting shareholders' interest (Bushman \& Smith, 2001). In addition, the controlling mechanism is necessary to become a segregating system between ownership and control (John \& Senbet, 1998; Upadhyay et al., 2014).

\subsection{Corporate Governance}

It is the director who plays the role of supervision in corporate governance (Bushman \& Smith, 2001; Upadhyay et al., 2014). Adams \& Ferreira (2007) assign board of directors as the highest legal authorities in company decision making. The manager sometimes makes a decision that contradicts with shareholders interest, and director becomes the mediator to resolve these differences by approving and pushing towards the change (Adams \& Ferreira, 2007). 
In general, there are two types of structure on the board of directors that consist of one-tier (unitary or sole board) and two-tier (dual board) (Adams \& Ferreira, 2007). Adams \& Ferreira (2007) discuss entirely regarding the one-tier and two-tier systems. In one-tier structure, advisory and supervision function are combined (Adams \& Frreira, 2007). Besides, that system allows CEO duality, which enables president director to function as the executives (management) and as part of the board of directors (Krause et al., 2014). There is a clear distinction between management board or board of director performance in operational sectors and supervisory board or board of commissioner, which mitigate the result on duality (Hermawan, 2011) ${ }^{1}$.

\subsection{Female commissioner}

Research by Dowling \& Aribi (2013) show that there is a negative relationship between the existence of a female commissioner and some acquisitions, due to the lower overconfidence on women compared to men. Furthermore, Dowling \& Aribi (2013) imply that low-level acquisition could be brought about by a psychological factor related to different risk taker preference in women and men.

In general, Campbell \& Minguez-Vera (2008) argue that the supervision role of director depends on the involvement in qualifications, experiences, and contributions toward many things related to the director, level of share ownership in one company and payroll scheme applied. One of the aspects that can be assumed to increase supervision is the existence of a female commissioner as part of directors. Campbell \& Minguez-Vera (2008) hope that with the presence of a female commissioner will increase the shareholders' value as it is to broaden the perspective of other director members. Campbell \& Minguez-Vera (2008) view there is a positive relationship between the existence of a female commissioner and the company value. A female commissioner is considered to be able to affect the company's value.

\footnotetext{
${ }^{1}$ In the one-tier board, the term of board of director is party with supervision function to control the executive works. On the contrary, terms of the board of director in the two-tier board represent the management parties or executives as the parties that maintain the daily activities of a company, whereas board of commissioner has the same function as board of director in the one-tier board governance.
} 
In a global perspective, Arun et al. (2015) reveal the issues related to increasing gender diversity on company's directors have already become world concerns. It can be proven by formal regulation that obligates women involvement in the board of directors in Swedish, Norwegian and Spanish companies (Gul et al., 2013). Also, European United (EU) commission approves to increase gender equality in nonexecutives board structure in public companies at the year of 2020 (Farag \& Mallin, 2016).

Adams \& Ferreira (2009) suggest that, first, gender diversity on the board of directors have the significant impact on the director's input. The input is in the form of high-level involvement to solve company problems. Second, the female commissioner has substantial roles in company's director governance. Third, Adams \& Ferreira (2009) document that companies with bad performance have more diverse members of directors in gender. Specifically, the negative relationship can be explained by connecting it with the existence of female commissioner and will benefit the company with weak shareholder rights due to an increase of supervision that can increase the value of the company. On the contrary, with the increase of oversight applied in strong shareholder rights environment will result in the adverse effect on the company. Adams \& Ferreira (2009) re-strengthen their results by stating that gender diversity among the board of director will create close supervision. However, when considering gender diversity as mandatory, it will damage the company that already has good governance due to the increase of oversight may lead to decreasing the productivity (Adams \& Ferreira, 2009).

Furthermore, Farrel \& Hersch (2005) find that gender diversity boards will result in a good company performance. In another side, results from event study show that there is no significant market response toward the female commissioner designation (Farrel \& Hersch, 2005). Conversely, Kang et al. (2010) document that capital markets positively respond toward appointment of female commissioner as top-level management. These responses provide an insight of investor generally receptive toward designation of female commissioner and adjustment in expectation of future value (Kang et al., 2010). Following Gul et al. (2013), they comment that many 
previous studies document ambiguous evidence. On the other hand, director diversity is able to push the performance with the increase of decision-making capacity. Moreover, this diversity will give impact in the declining of group performance due to the escalation of conflict among that group. The existence of female commissioner is expected to increase the transparency and encourage the information content that will implicate to share price (Gul et al., 2011).

Based on the motivation regarding the issue of enhancing the gender equality in director level in the company, Arun et al. (2015) document that gender in the board of director can be proxied by the total amount of female commissioner as independent director and executives director, alongside with existence of women as Chief Financial Officer (CFO) effect on the quality of financial reporting. The more women proportion as the board of directors will show conservatism in practice and policy.

By using the setting sample on US public companies, Francis et al. (2015) strengthened Arun et al. (2015) by showing the difference in decision-making preferences between men and women. Systematic differences to be marked by conservative choice are reviewed by women sensitivity level towards high-level risk than men. Francis et al. (2015) explain the choice to examine regarding conservatism in accounting that will give the exact reflection towards manager's behavior in dealing with risk. Furthermore, the results show that female commissioner has a high level of independence (Abbott et al., 2012). These implications provide an insight into gender diversity which enables to increase supervision rather than homogeneous members of director (Abbott et al., 2012).

The research conducted by Srinidhi et al. (2011) test the connection between the female commissioner and earnings quality that will be used as the primary basis in conducting this research. Srinidhi et al. (2011) develop a logical thinking about the role of a female commissioner such as the role of independent director. Srinidhi et al. (2011) propose the argument that with diversity resulting from director's gender can be benefiting the company. Srinidhi et al. (2011) results show that the company consisting of the female commissioner will have a higher earnings quality by enhancing the supervision. The measurement of female commissioner reflects three 
aspects, namely female as the member of the board of directors, the member of nonexecutive directors, and the member of the audit committee.

\subsection{Managerial Ability}

Bertrand \& Schoar (2003) begin their research with the question "How much do individual managers matter for firm behavior and economic performances?" Our research is motivated by previous studies focusing only on the characteristics of the company, industry, or market to explain the company's behavior and performance. Most of those researches do not take into account the role of individual manager which potentially affects (Bertrand \& Schoar, 2003). Bertrand \& Schoar (2003) show evidence that manager fixed effects become decision factor in determining a company's variable practices. Specifically, the individual manager plays a role in giving significant and economic impact toward the decision of acquisition or diversification, dividend policy, interest coverage and other cost decreasing policy (Bertrand \& Schoar, 2003).

Next, Demerjian et al. (2012) propose a model in measuring managerial ability which is based on Data Development Analysis (DEA). It is usually used for measuring in industrial level; then it got the modification to be used in the firm level. Several components are used to measure managerial ability: cost of inventory, general \& administrative expense, fixed asset, operating lease, past R\&D expenditure, and intangible asset (Demerjian et al., 2012). In this model, Demerjian et al. (2012) expect that higher managerial ability would ease them to understand the trend of technology and industry, more reliable in predicting the demand of the product, including investment in the higher amount of project and efficiency in controlling the employee than the unreliable manager. In short, the more capable the manager, the more efficient and effective the company is.

Choi et al. (2015) analyzes the operational ability of CEO to explain the relationship between current accruals and future cash flow. CEO with high capacity will be effective and efficient in applying operational policy and able to provide reflective future cash flow in current accrual (Choi et al., 2015). By observing data 
from the year of 2000 until 2011, Choi et al. (2015) find that accruals reflecting information regarding future cash flow in the case of the manager do have a high level of operational ability. Choi et al. (2015) claim that results could complement the measurement of managerial ability by Demerjian et al. (2012) by showing not only accuracy of judgment and estimation ability in mapping current accrual with future cash flow, but also the need of ability on arranging an efficient operational decision. Furthermore, Choi et al. (2015) strengthen the research of Bertrand \& Schoar (2003) regarding specific characteristics of CEO (managerial) as an essential dimension in quality of earnings.

Dejong \& Ling (2013) focus on the impact of specific individual in accrual that could not be explained by the company's characteristics. The results show that individual manager significantly has a chance to influence the company's policy and practice (Dejong \& Ling, 2013). Specifically, the president director affects the accrual by using various policies in the company (Dejong \& Ling, 2013).

Another managerial ability measurement in the form of GAI is developed by Custodio et al. (2013). The GAI analysis is based on president director's work experience in developing previous public companies. Custodio et al. (2013) claim the model is able to measure expertise and skills which can be transferred or moved from companies and industries embedded with the individual as president director.

Measurement with GAI could be classified as managerial ability in generalist and specialist groups (Custodio et al., 2013). A president director is categorized as generalist if his or her GAI value is above the average and as specialist if his or her GAI value is below the average. (Custodio et al., 2013). The high value of GAI possessed by president director is higher than that owned by president director in operating the company. Graham et al. (2013) are interested in understanding president director's behavior as the primary role in the company decision maker. Having surveyed, Graham et al. (2013) conclude that president director has a high tolerance to risk, more opportunist and has the significant relationship with company's characteristics. 
According to the variety of managerial ability measurement, we employ GAI measurement by Custodio et al. (2013) on the rationale that this measurement captures the experience of management. On top of that, this measurement is strengthened by upper echelon theory (Hambrick \& Mason, 1984) which states executive's cognitive and emotion are constructed during carrier experiences. Hambrick \& Mason (1984) assume that executives who build carrier in only one organization would relatively have limited perspectives. Therefore, the GAI is expected to properly show the ability of president director.

\subsection{Earnings Quality}

Financial accounting information is the product of accounting governance and external reporting system which is used to measure and publish the audit result in qualitative data related to the financial position and company performance (Bushman \& Smith, 2001). Moreover, profit is one of the accounting information sources that have fundamental roles in determining share price or even evaluating and deciding executive compensations (Bushman \& Smith, 2001). Therefore, the quality of appropriate profit becomes the basis to know the role of a company's governance.

One of potential distortion that decreases the accounting system is the ability to reflect earnings reporting implementation error and earnings management (Dechow et al., 2010). Specifically, the accounting measurement system in accrual can be the proxy for earnings quality (Dechow et al., 2010). This accrual decision is based on the company's policy or managerial discretion. DeFond (2010) completes the Dechow et al. (2010) research by adding several observations from earnings quality literature, abnormal accrual measurement as part of them. DeFond (2010) explain that there are only three models from many choices which can be used to measure accrual, namely Jones (1991), Dechow \& Dichev (2002), and Francis et al. (2005) models.

Accrual model proposed by Francis et al. (2005) is based on earnings quality from Dechow \& Dichev (2002) with the submitted modification by McNichols (2002) to include revenue and property, plant and equipment components as explanatory variables. Then, Francis et al. (2005) research model is able to improve Dechow \& Dichev (2002) model with the decomposition of accrual components on innate factors 
and discretionary factors shown by accrual. Francis et al. (2005) assume that cash flow is the primitive elements evaluated by the investor. Therefore identification of accrual quality becomes a crucial factor in earnings quality. High-quality accrual shows information for investors regarding reflected earnings profit into cash flow.

\subsection{Hypothesis Development}

\subsubsection{The relation between the female commissioner and earnings quality}

Based on agency theory (Jensen \& Meckling, 1976), there is a conflict of interest between shareholders as principals and managers as agents. To minimize the conflict, corporate governance mechanism ought to be established to supervise management performance (John \& Senbet, 1998; Upadhyay et al., 2014). One of this mechanism is controlled by the director (Bushman \& Smith, 2001; Upadhyay et al., 2014).

Considering the weak shareholder rights system in Indonesia, female commissioner role as the form of diversity in top-level management can be beneficial for the company (Adams \& Ferreira, 2009). Campbell \& Minguez-Vera (2008) document that female commissioner affects the value of the company. Furthermore, Adams \& Ferreira (2009) comment that a female commissioner has a high involvement in solving every problem in the company, including in governance and increasing supervision system.

Based on other perspectives, gender diversity in board of directors results on good company performance by the broader views and experiences (Farrel \& Hersch, 2005) also affects the quality of financial reporting (Arun et al., 2015). Also, female appointment as director of the company is positively responded by market (Kang et al., 2010). Contradicting with Kang et al. (2010), Farrel \& Hersch (2005) show insignificant result between market responses with appointment of the female commissioner. Besides, Hanani \& Aryani (2011) document that gender diversity on the board of commissioner negatively relates to company performance. Gul et al. (2013) argue that diversity in directors would give a chance for group conflict, that will decrease the performance.

According to various proxies for earnings quality (Dechow et al., 2010), the existence of female commissioner increases earnings quality, reflected by lower-level 
of restatement (Abbott et al., 2012). Moreover, the increased information content occur by the high level of transparency (Gul et al., 2011). In details, Srinidhi et al. (2011) and Abbott et al. (2012) explain that female commissioners tend to push effectiveness in supervising. A strict supervision of manager performance is able to increase the manager's accuracy and carefulness in decision-making, which implicates the correctness of accrual discretion. Therefore, female commissioner can be conjectured to have a positive impact toward earnings quality. We propose hypothesis 1 (H1) as follows.

\section{H1: Female commissioner positively affects earnings quality.}

\subsubsection{The relation between president director's ability and earnings quality}

Bertrand \& Schoar (2003) and Dejong \&Ling (2013) explain managerial specific characteristics as the determinant factor in every company practical variables. Specifically, managerial characteristics reflecting managerial ability positively impact the company. Demerjian et al. (2012) argue that capable manager produces higher revenue in specific resources or even minimize the use of resources to achieve the particular target in revenue. Choi et al. (2015) show that managerial ability is of the essential contents in earnings quality.

In their research, Demerjian et al. (2013) relate managerial ability to earnings quality and find that managerial capacity increases earnings quality. Also, Choi et al. (2015) show that management ability in handling operational activities become a determinant factor in current accrual information for future cash flow. Furthermore, Demerjian et al. (2013) comment the accruals reported by capable managers reflect the real condition because the accruals are determined by correct judgment and estimation. Then, a competent manager with work experience in many company sectors and industries is expected to solve a complex problem (Custodio et al., 2013). According to the experience they have, president director as the chief of the executive (management) will take the decision correctly so that the accruals decision will reflect

the real condition of the company. Thus, president director's ability can be expected to 
have a positive effect on earnings quality. Based on the above arguments, we advance the following hypothesis.

H2: High president director's ability has a positive influence on earnings quality.

\subsubsection{The relation of female commissioner and president director's ability to earnings quality}

Previous studies that relate female's role to board of directors provide inconsistent results. Some studies show that female commissioner has a positive role (Adams \& Ferreira, 2009; Campbell \& Minguez-Vera, 2008; Farrel \& Hersch, 2005; Arun et al., 2015, Kang et al., 2010; Srinidhi et al., 2013) and some others show a negative role (Farrel \& Hersch, 2005; Hanani \& Aryani, 2011) and still remaining others show no influence of female commissioner (Kusumastuti et al., 2007; Mardiyati, 2016). Overall, those studies do not take into account specific managerial aspects in the analysis.

Some studies (Adams \& Ferreira, 2009; Srinidhi et al., 2011; Abbott et al. 2012) show that the existence of female commissioners improves supervision. Because of their ability, president director tends to be motivated to take a decision (Mishra, 2014). Besides, capable president directors tend to have high tolerance towards risk and to act opportunistically (Graham et al., 2013). With consideration toward those possibilities, female commissioners with high-level of conservatism (Francis et al., 2015; Arun et al., 2015) and tend to avoid risky decision (Dowling \& Aribi, 2013; Francis et al., 2015) will increase their supervision.

This supervision function will be strengthened when the supervising president directors have a highly excellent ability to maintain the company. Conversely, lower ability president director tends to dilute the female commissioner's control. The supervision is used to ensure that the policy established by president director can be aligned with the investor's interests instead of their own interests. On the other hand, when female commissioners assume that the managing director has a low ability, they will conduct loose oversight because it is easier for them to control and investigate in 
case of a violation. Therefore, the high capability of the president director can enhance the role of female commissioners who ultimately implicated in the generation of high earnings quality.

\section{H3: The president director's ability strengthens the role of female commissioner} towards earnings quality.

To clearly and concisely explain the relationship between variables, exhibit 1 shows the research framework we propose.

\section{Exhibit 1}

Research Framework

Female Director
$\mathrm{H} 1(+)$

$$
\text { H3 (+) }
$$

$\mathrm{H} 2(+)$

\section{Managerial Ability}

\section{Research Method}

\subsection{Sample Selection}

The sample selection is based on non-profitability sampling method in the form of purposive sampling. Several criteria become the bases for sample selection as shown in Table 1.

Table 1

Sample Selection 


\begin{tabular}{|l|l|}
\hline Criteria & $\begin{array}{l}\text { Number of } \\
\text { Companies }\end{array}$ \\
\hline Manufacturing companies listed on IDX in the year of 2011-2015 & 875 \\
\hline (-) Companies conducting mergers and acquisitions & $(34)$ \\
\hline (-) Companies with incomplete data & $(134)$ \\
\hline Total & 707 \\
\hline
\end{tabular}

Source of Data: BvD Osiris and Bloomberg

The sample of this research is focused on manufacturing company since it has domination in the Indonesia Stock Exchange. So, by using this sector, it can show the characteristics of overall companies in the capital market and strengthen the ability to generalize the results. The determination of observation period starting from 2011 until 2015 is based on the statement of Francis et al. (2005). In their research, Francis et al. (2005) state that the examination needs seven-year observation to include the calculation of cash flow on previous years and cash flow in one-year ahead to analyze the residual of accruals. The data of cash flow on previous year are taken from company financial report of the year 2010, whereas data cash flow in one year ahead taken from financial report of the year 2016. Besides, the year 2010 is determined as the beginning period to avoid the effect of the global economic crisis data that occurred during 2008-2009. If these data during the crisis periods were used in the analysis, it might distort the result of this research.

\subsection{Variable Measurements}

Some identification of analysis method is used to test the relation between female commissioner, president director ability, and earnings quality.

a. Female commissioner

Female commissioner measurement is based on the total percentage of female members assigned as the board of commissioners (Farag \& Mallin, 2016). The total of directors data could be obtained from the company's annual report that can be accessed through the Indonesia Stock Exchange (IDX) official website.

b. President director's ability 
General Ability Index (GAI) developed by Custodio et al. (2013) is used to measure president director ability, which is the measurement that covers overall work experience of president director in public companies before the current position. Custodio et al. (2013) construct five components in measuring GAI, which are (1) a number of positions, (2) a number of firms, (3) a number of industries, (4) CEO experience dummy, and (5) conglomerate experience dummy. The data of each component can be gathered from financial reporting, especially at the part of a biography of president director. After that, these five components are composed using principal component analysis (PCA). This analysis is usually used to classify each of the components that has relation to one factor. Because of that, the multicollinearity problem can be minimized.

The PCA will classify the components as two factors, which are a factor I that consists of component numbers 2 and 4, whereas factor II consists of component numbers 3 and 5. Component number 1 is eliminated because it generates the insufficient result as the requirements of PCA. Afterward, each factor will generate the particular number, and its number will be summed up to gather the amount of president director ability. The higher number of the result show the higher capacity of president director.

c. Earnings quality

Earnings quality measurement is based on discretionary estimation error model adopted from Francis et al. (2005). This model is a combination of Dechow and Dichev model (2002), modified Jones model, and McNichols's proposed model. Here is the formula:

$\left.\left.\left.\left.\mathrm{TCA}_{\mathrm{i}, \mathrm{t}}=\alpha_{0, \mathrm{i}}+\alpha_{1, \mathrm{i}} \mathrm{CFO}_{\mathrm{i}, \mathrm{t}-1}+\right]_{2, \mathrm{i}} \mathrm{CFO}_{\mathrm{i}, \mathrm{t}}+\right]_{3, \mathrm{i}} \mathrm{CFO}_{\mathrm{i}, \mathrm{t}+1}+\right]_{4, \mathrm{i}} \Delta \mathrm{Rev}_{\mathrm{i}, \mathrm{t}}+\right]_{5, \mathrm{i}} \mathrm{PPE}_{\mathrm{i}, \mathrm{t}}+\varepsilon_{\mathrm{i}, \mathrm{t}}$

For the first step, Francis et al. (2005) use this formula to examine each of 48 industry group. This calculation will generate the residual (error) which represents the accrual quality. The higher this accrual amounts, the lower the quality of earnings. The accrual number consists of innate and discretionary 
factors. To distinguish between the innate and discretionary factors, Francis et al. (2005) hold second step of examination. So that, Francis et al. (2005) are be able to obtain the specific error that was caused by the managerial and error that cannot be controlled by the firm. The second step can be held only if there is some group of a sample that will be tested. For the current research, the examination is only held for the first because only one industry is used as the sample, which is manufacturing companies. Consequently, the data of this research does not meet the requirement of the second step examination.

\section{a. Hypothesis Testing}

Multiple Regression analysis is used to test the hypothesis with the function (1) as it follows:

$$
\begin{aligned}
\text { EarnQual }_{i, t} & =\alpha_{0}+\alpha_{1} \text { FemDir }_{i, t}+\alpha_{2} \text { PresAblty }_{i, t}+\alpha_{3} \text { FemDir }_{, t} * \text { PresAblty }_{i, t}+\alpha_{4} \\
& \text { Leverage }_{i, t}+\alpha_{5} \text { Size }_{i, t}+\varepsilon_{i, t}
\end{aligned}
$$

Where;

EarnQual $_{i, t} \quad$ : Earnings quality measured by the accrual model proposed by Francis et al. (2005)

FemDir $_{i, t}$

: Female commissioner measured by the total percentage of female members in commissioners (Farag \& Mallin, 2016)

PresAblty ${ }_{i, t}$

: Managerial ability measured by the General Ability Index (GAI) (Custodio et al., 2013)

FemDir,$t *$ PresAblty $_{i, t}$ : An interaction between female commissioners with managerial ability in company $i$ at the year of $t$

Leverage,

: A total amount of liability toward the amount of total asset in company $i$ at the year of $t$

Size $_{i, t}$

: Company size measured by log of the total asset in the company $i$ at the year of $t$

$\varepsilon_{i, t} \quad: \quad$ Error 
This examination only uses two control variables - leverage and size - which are commonly used and already proved by many studies about its influence towards earnings quality.

\section{RESULTS AND DISCUSSION}

\subsection{Descriptive Statistic}

Table 2 presents descriptive of our data. Following the data description, we analyze in detail female commissioner and president director's ability.

Table 2

Descriptive Statistics

\begin{tabular}{lcccccc}
\hline \multicolumn{1}{c}{ Variables } & Maximum & Minimum & Mean & Mode & $\begin{array}{c}\text { Mode } \\
\text { Frequencies }\end{array}$ & Correlation \\
\hline $\begin{array}{l}\text { Earnings Quality } \\
\begin{array}{l}\text { Female } \\
\text { commissioner }\end{array}\end{array}$ & 2.85 & 0 & 0.09 & 0.02 & 72 & 1 \\
$\begin{array}{l}\text { President Director } \\
\text { Ability }\end{array}$ & 0.80 & 0 & 0.11 & 0 & 466 & 0.045 \\
$\begin{array}{l}\text { Female } \\
\text { commissioner*Pre }\end{array}$ & 1.70 & -1.02 & -0.03 & -1.02 & 193 & 0.001 \\
$\begin{array}{l}\text { sident Director } \\
\begin{array}{l}\text { Ability } \\
\text { Leverage }\end{array}\end{array}$ & -0.68 & -0.03 & 0 & 466 & 0.020 \\
Company Size & 4.98 & 0 & 0.56 & 0.67 & 18 & $0.415^{*}$ \\
\hline
\end{tabular}

*Pearson correlation test with a level of significance of $5 \%$

This research uses six variables, which consist of one dependent variable and five independent variables. Earnings quality becomes the dependent variable, whereas female commissioner, president director ability, the interaction between the female commissioner and president director ability are independent variables. The remaining variables, leverage and company size, are used as control variables.

In earnings quality, maximum value reaching 2.85 , as for minimum is 0 . The result of earnings quality calculation is positive, negative and also zero. The measurement of earnings quality is usually used in the earnings management. When calculating the earnings management, the result is processed to be an absolute number 
because the purpose is to investigate the existence of distortion instead of examining how the way to do the earnings management which is represented by the positive or negative sign at the result. Adopting that treatment, this research also calculates the earnings quality as the absolute number. Because of that, the minimum amount of earnings quality is zero. Average of earnings quality is 0.09 , and the mode is 0.02 with the frequency of 72 times. Of the 707 companies, 72 companies had earnings quality in the amount of 0.02 .

Female commissioner is measured by women percentage in the board of commissioners. The highest percentage of the female commissioner is 0.80 and minimum is 0 . The minimum value also becomes the mode with frequencies of 466 times. That means that out of 707 companies, 466 companies do not have a female commissioner. The correlation value between the female commissioner and earnings quality show Pearson values of 0.045 with a probability value of more than 0.05 . The results indicate the chance of none significant relation between percentage of the female president director and earnings quality.

The next variable which is president director ability has a maximum value of 8.56 with the minimum of -1.02 , as the average is 0 . That means there is president director (CEO) with the highest ability of 8.56, as one with the lowest value of -1.02 . The lowest value can be categorized as the mode with frequencies of 193 times. That gives a sign that from 707 president directors, 193 among them have the lowest ability. Moreover, the average of president director ability is 0 . The correlation value between president director ability and earnings quality is 0,001 which more significant than 0.05 . That value indicates that there is no connected relation between president director ability and earnings quality in hypothesis testing.

Moderating variable in the form of interaction between the female commissioner and president director ability shows maximum of 1.70 and minimum of -0.68 . That shows the company with a female commissioner, and president director's ability has the maximum value of 1.70 , and there is the company with the value of -0.68 . On average, the company with a female commissioner and president director ability has the value of -.03 . The value of mode is 0 with the frequency of 466 times. The same 
other two variables, a correlation value between the female commissioner ability and president director ability has the level of significance more than 0.05 with Pearson value of 0.020 . That value refers to the weak relationship between those interactions with the company's quality of earnings.

Leverage as the variable control with the maximum value of 4.98 and minimum of 0 . The result shows that there is a company with the highest leverage of 4.98 and there is a company with no leverage. For average, 707 sample firms give the average leverage of 0.56 . The mode is 0.67 with frequencies of 18 times. That means, there are 18 companies with the leverage of 0.67 . Next, the slope of leverage is 4.59 with kurtosis of 31.16. Different from other previous variable correlation, leverage and earnings quality correlation has less significance from 0.05 with the correlation of 0.415. This shows a strong relationship between leverage and company earnings quality.

The second control variable, company size, is measured by total asset amount. The maximum value of company size is 7.28 , and the minimum amount is 2.34 . The average of sampled company size is 5.12. Company size of 5.37 becomes mode with the frequency of 11 times. The same as the leverage, company size has a correlation value of 0.085 with significantly less than 0.05 . That indicates that company size has a strong relationship with earnings quality.

Based on Table 3 below, the overall amount of directors are 2,862 directors that consist of 2.573 male directors and 289 female commissioners. According to that amount, the total of female commissioners constitutes only $10 \%$ of the overall amount of directors

Table 3

Amount of Female commissioners

\begin{tabular}{lcc}
\hline \multicolumn{1}{c}{ Explanation } & Total & Percentage \\
\hline Board of Directors & 2,862 & $100 \%$ \\
Female commissioners & 289 & $10 \%$ \\
Male Directors & 2,573 & $90 \%$ \\
\hline
\end{tabular}




\subsection{Measuring President Director's Ability}

General Ability Index (GAI) developed by Custodio et al. (2013) is used to measure managerial ability. The range of measurement consists of president director's (CEO) work experience in different companies and industries in the form of five variables.

Table 4

Communalities Value

\begin{tabular}{cc}
\hline Variables & Communalities Value \\
\hline X1 & 0.261 \\
X2 & 0.658 \\
X3 & 0.669 \\
X4 & 0.744 \\
X5 & 0.623 \\
\hline
\end{tabular}

Based on Table 4, the amount of X1 is only 0.261, whereas Hair et al. (2010) state that for PCA examination, each variable has to earn communalities values of 0.50. Therefore, $\mathrm{X} 1$ is eliminated from the analysis. GAI result with using PCA analysis is shown in Table 5. There are two factors established, which are the factor I and factor II. Factor I consist of X2 and X4, as for factor II include of X3 and X5. The variables $\mathrm{X} 2$ and $\mathrm{X} 4$ tend to measure president director ability in company level, as for X3 and X5 measure the ability in industrial level. Therefore, the established factor can recognize as ability in company and factor as ability in the industry.

Table 5.

Matrix Rotation Components

\begin{tabular}{ccc}
\hline & \multicolumn{2}{c}{ Components } \\
\cline { 2 - 3 } Variables & 1 & 2 \\
\hline X2 & 0.808 & -0.183 \\
X3 & 0.319 & 0.778 \\
X4 & 0.841 & -0.015 \\
X5 & -0.088 & 0.882 \\
\hline
\end{tabular}




\section{a. Hypothesis Results}

During classic assumption testing, several recovery steps are conducted due to heteroscedasticity problem. First, dependent variables are transformed. Transformation affects sample reduction from 707 to 668 samples. Then, there was heteroscedasticity problem in leverage variable, making it excluded from research model. With the overall fulfillment of classic assumption testing (normality, multicollinearity, heteroscedasticity, and autocorrelation), hypothesis testing can be done with a regression test. Table 6 presents the results of hypotheses testing.

Table 6.

Regression Results

\begin{tabular}{lccc}
\hline \multicolumn{1}{c}{ Variables } & Coefficient & t-Statistics & Prob(t-value $\leq$ ) \\
\hline $\mathrm{a}_{0}$ & -1.609 & -5.607 & 0.0000 \\
Female commissioner & -0.354 & -1.642 & 0.0505 \\
President Director Ability & -0.004 & -0.143 & 0.4430 \\
Female commissioner* President Director & 0.334 & 1.748 & 0.0405 \\
Ability & -0.241 & -4.360 & 0.0000 \\
Company Size & & & \\
\hline
\end{tabular}

Based on Table 6, it can be formulated with the following function:

Earnings Quality $=-1.609-0.354$ Female commissioner -0.004 President

Director Ability + 0.334 Female commissioner* President Director Ability - 0.241 Company Size

Our conjecture is that the coefficient of female commissioner has a positive sign. We, however, find that the coefficient is -0.354 with the one-tail probability value of slightly more than 0.05 . The negative sign of the coefficient shows that we fail to find that female commissioner has a positive impact on earnings quality. We 
also predict that president director's ability positively affects the earnings quality. Although we find that the coefficient has a positive sign, its probability value is more than 40 percent. The $t$ value indicates that we do not find the effect on earnings quality of president director's ability. We, however, find that the coefficient of interaction of female commissioner and president director's ability is 0.334 and significant with the probability value of 0.0405 . Thus, the interaction between these two variable statistically, significantly impacts on earnings quality. Next, the coefficient of control variable, company size, is negative 0.241 with the probability value of 0.000 .

\section{b. DISCUSSION}

The fact that we do not find the positive effect on earnings quality of female commissioner needs explanation. In our opinion, the following arguments explain our failing to support our hypothesis 1 . In the cultural perspective, Indonesian strongly assume that men are more eligible to get assigned an important position in the company rather than women (Kusumastuti et al., 2007). This implicates towards less number of women employed in the board of directors. Referring to descriptive data, from the total of 2,862 boards of directors, only 289 were female commissioners. Srinidhi et al. (2011) and Abbott et al. (2012) comment that female commissioner is able to increase the supervision, but with less number of a female commissioner, the optimal oversight could not be conducted, which results in management still freely use their discretion and judgment for getting profit, without increasing cautious and estimation accuracy. With that being said, the female commissioner by her own may not have strong association with company earnings quality.

In the second hypothesis, we predict that president director's ability has a positive influence towards earnings quality. Table 6 , however, shows the probability value of 0.4403 although the coefficient shows positive sign. Therefore, H2 is not supported. This result is different from Demerjian et al. (2013) or even Francis et al. (2008) results. Demerjian et al. (2013) document a positive relationship between managerial ability and earnings quality. In another side, Francis et al. (2008) state that managerial 
ability, could be measured in president director's reputation, negatively relates to company's quality of earnings.

President director's work experiences in every company and industries could not ensure high quality of company earnings. Dejong \& Ling (2013) state that even president director has the same impact as CFO in accrual accounting, total and abnormal accrual, but CFO tend to have a significant effect toward abnormal accrual rather than president director. Dejong \& Ling (2013) add that to affect accrual, CFO uses choice (discretion) accounting, as for president director tend to use the company's policy.

In other side, earnings mean the value comes from management discretion toward accounting numbers. That means, even president director with high ability is unable to affect earnings quality because he or she does not use accounting discretion. Therefore, capable president director will not have a connection with earnings quality.

Hypothesis three covers up the interaction between the president director's ability and female commissioner towards earnings quality. The interaction of female commissioner and president director ability has a positive coefficient with the probability value of 0.0405 . This means that the interaction between female commissioner and president director has a positive effect on earnings quality.

President director with good ability tends to take a decision based on its own interest, instead of shareholders interest. Furthermore, Graham et al. (2013) state that president director has a higher tolerance for risk and opportunistic behavior. In another side, Francis et al. (2015) and Arun et al. (2015) comment that female commissioner tends to have a high conservatism. Dowling \& Aribi (2013) and Francis et al. (2015) add that female commissioner tends to avoid a risky decision.

With consideration of different tendencies between a female commissioner and president director, the female commissioner will play her function as a strict supervisor to ensure that president director will do his role based on shareholder interest. The existence of supervision encourages the managerial side to increase their cautious in estimation and decision-making, to achieve a good quality of earnings. 
Therefore, it can be concluded that the interaction of female commissioner and president director ability has a positive influence on earnings quality of the company.

Related to control variable, company size has a significance value on 0.000 with a coefficient of -0.241. Although the coefficient shows a negative sign, the interpretation is that company size has a negative relationship with the earnings quality. This is because the measurement of earnings quality is measured by the amount of accruals. Higher amount of the accruals reflects lower the level of earnings quality. Because of that, even the coefficient shows the negative amount, and it can be interpreted that company size has a positive influence toward earnings quality. Bigger companies show lower accruals. Lower accruals reflect more quality of earnings. So, the bigger the company, the more quality is the earnings. Once a company makes a violation, the stakeholders will lose the trust that implicates the damage of company reputation. Because of that, bigger company has strong encouragement to present their condition faithfulness, especially reporting their income as the performance measurement.

\section{Conclusion, Implication, and Limitation}

The purpose of this research is to examine the relationship of a female commissioner, president director's ability, and earnings quality. We use agency theory by Jensen \& Meckling (1976) which explores contractual relationship between principals and agents. On that relation, conflict of interest appeared that affects towards supervision cost appeared for controlling the agents to conduct based on principals interest. In the corporate governance system, the supervision mechanism is held by the director. The existence of a female in the board of directors is expected to give positive influence toward earnings quality. Srinidhi et al. (2011) and Abott et al. (2012) state that female commissioner efficiently improve the effective supervision.

Based on statistical testing, we find the followings. First, there is no sufficient empirical evidence that female commissioner has a positive impact on earnings quality. Second, there is no enough evidence that president director's ability positively impacts towards earnings quality. Third, there is enough empirical evidence that the 
interaction between female commissioner and president director's ability has a positive impact on earnings quality. With these findings, it can be concluded that a female commissioner will do her function optimally as the supervisor when president director she oversees has the good ability.

Our study has some the following limitations. First, variable measurement for female commissioner is based on the total percentage of the female member of the board of commissioners without concern about position level in that board of commissioners. Future research should add different weight on the position of female commissioner, for example, female commissioner is assigned as commissioner president give higher weight rather than normal commissioner position.

Second, our research uses new measurement to examine managerial ability, which is the General Ability Index (GAI) developed by Custodio et al. (2013). This measurement is unable to describe the ability of president director correctly, especially work experience in various industries. The GAI determines us to measure the managerial ability by working experience in the industry and conglomerate firms that is only determined based on SIC code. The code is owned only by the public company. In fact, president director's work experience is actually not only in public company.

Third, GAI measurement covers up managerial ability owned by president director (CEO), according to Dejong \& Ling (2013), CEO has a relatively small role in using accounting discretion. Therefore, subsequent research should use other measurements, such as Data Envelopment Analysis (DEA) developed by Demerjian et al. (2013) to measure the connection between managerial ability and earnings quality.

Fourth, rRelated to managerial ability, longitudinal or time-series analysis can be conducted to know the role of capable CEO in the company. Due to the probability of the CEO role will be seen in long-term company performance. 


\section{References}

Abbott, L. J., S. Parker, and T. J. Presley. 2012. Female Board Presence and The Likelihood of Financial Restatement. Accounting Horizons. Vol. 26 (4): 607-629.

Adams, R. B., and D. Ferreira. 2007. A Theory of Friendly Boards. Journal of Finance. Vol. 62 (1): $217-250$.

Adams, R. B., and D. Ferreira. 2009. Women in The Boardroom and Their Impact on Governance and Performance. Journal of Financial Economics. Vol. 94 (2): 291-309.

Arun, T. G., Y. E. Almahrog, and Z. A. Aribi. 2015. Female commissioners and Earnings Management: Evidence from UK Companies. International Review of Financial Analysis. Vol. 39: 137-146.

Bertrand, M., and A. Schoar. 2003. Managing with Style: The Effect of Managers on Firm Policies. Quarterly Journal of Economies. Vol. 118 (4): 1169-1208.

Bushman, R. M., and A. J. Smith. 2001. Financial Accounting Information and Corporate Governance. Journal of Accounting and Economics. Vol. 32 (1): 237-333.

Campbell, K., and A. Minguez-Vera. 2008. Gender Diversity in The Boardroom and Firm Financial Performance. Journal of Business Ethics. Vol. 83 (3): 435-451.

Choi, W., S. Han, S. H. Jung, and T. Kang. 2015. CEO's Operating Ability and The Association between Accruals and Future Cash Flows. Journal of Business Finance and Accounting. Vol. 42 (5) \& (6): 619-634.

Christian, C. 2004. The Value-Relevance of Earnings and Operating Cash Flows During Mergers. Managerial Finance. Vol. 30 (11): 16-29.

Claessens, S., S. Djankov, and L. H. P. Lang. 2000. The Separation of Ownership and Control in East Asian Corporations. Journal of Financial Economics. Vol. 58 (1): 81-112.

Custodio, C., M. A. Ferreira, and P. Matos. 2013. Generalist versus Specialist: Lifetime Work Experience and Chief Executive Officer Pay. Journal of Financial Economics. Vol. 108 (2): 471-492.

Dechow, P., W. Ge, and C. Schrand. 2010. Understanding Earnings Quality: A Review of The Proxies, Their Determinants, and Their Consequences. Journal of Accounting and Economics. Vol. 50 (2): 344-401.

Dechow, P. M., and I. D. Dichev. 2002. The Quality of Accruals and Earnings: The Role of Accrual Estimation Errors. The Accounting Review. Vol. 77 (s-1): 35-59.

Defond, M. L. 2010. Earnings Quality Research: Advances, Challenges and Future Research. Journal of Accounting and Economics. Vol. 50: 402-409. 
Dejong, D., and Z. Ling. 2013. Managers: Their Effects on Accruals and Firm Policies. Journal of Business Finance and Accounting. Vol. 40 (1-2): 82-114.

Demerjian, P., B. Lev, and S. McVay. 2012. Quantifying Managerial Ability: A New Measure and Validity Test. Managerial Finance. Vol. 58 (7): 1229-1248.

Demerjian, P. R., B. Le, M. F. Lewis, and S. E. McVay. 2013. Managerial Ability and Earnings Quality. The Accounting Review. Vol. 88 (2): 463-498.

Dowling, M., and Z. A. Aribi. 2013. Female commissioners and UK Company Acquisitiveness. International Review of Financial Analysis. Vol. 29: 79-86.

Farag, H., and C. Mallin. 2016. The Impact of the Dual Board Structure and Board Diversity: Evidence from Chinese Initial Public Offerings (IPOs). Journal of Business Ethics. Vol. 139 (2): 333-349.

Farrell, K. A., and P. L. Hersch. 2005. Additions to Corporate Boards. Journal of Corporate Finance. Vol. 11 (1): 85-106.

Fields, M. A., and P. Y. Keys. 2003. The Emergence of Corporate Governance from Wall St. To Main St.: Outside Directors, Board Diversity, Earnings Management, and Managerial Incentives to Bear Risk. The Financial Review. Vol. 38 (1): 1-24.

Firth, M., P. M. Y. Fung, and O. M. Rui. 2007. Ownership, Two-Tier Board Structure, and The Informativeness of Earnings - Evidence from China. Journal of Accounting and Public Policy. Vol. 26 (4): 463-496.

Francis, B., I. Hasan, J. C. Park, and Q. Wu. 2015. Gender Differences in Financial Reporting Decision Making: Evidence from Accounting Conservatism. Contemporary Accounting Research. Vol. 32 (3): 1285-1318.

Francis, J., A. H. Huang, S. Rajgopal, and A. Y. Zang. 2008. CEO Reputation and Earnings Quality. Contemporary Accounting Research. Vol. 15 (1): 107-147.

Francis, J., R. LaFond, P. Olsson, and K. Schipper. 2005. The Market Pricing of Accruals Quality. Journal of Accounting and Economics. Vol. 39 (2): 295-327.

Graham, J. R., C. R. Harvey, and M. Puri. 2013. Managerial Attitudes and Corporate Actions. Journal of Financial Economics. Vol. 109 (1): 103-121.

Gul, F. A., B. Srinidhi, and A. C. Ng. 2011. Does Board Gender Diversity Improve The Informativeness of Stock Prices? Journal of Accounting and Economics. Vol. 51 (3): 314338.

Gul, F. A., M. Hutchinson, and K. M. Y. Lai. 2013. Gender-Diverse Boards and Properties of Analyst Earnings Forecast. Accounting Horizons. Vol. 27 (3): 511-538.

Hair, J. F., Black, W. C., Babin, B. J., and Anderson, R. E. 2010. Multivariate Data Analysis, A Global Perspectives. Seventh Edition. New Jersey: Pearson Prentice Hall 
Hambrick, D. C., and P. A. Mason. 1984. Upper Echelon: The Organization as a Reflection of Its Top Managers. Academy of Management Review. Vol. 9 (2): 193-206.

Hanani, F., and Y. A. Aryani. 2011. Pengaruh Gender Dewan Komisaris, Gender Dewan Direksi, dan Kepemilikan Manajerial terhadap Kinerja Perusahaan. Wahana. Vol. 14: 719.

Hermawan, A. A. 2011. The Influence of Effective Board of Commissioners and Audit Committee on The Informativeness of Earnings: Evidence from Indonesian Listed Firms. Asia Pacific Journal of Accounting and Finance. Vol. 2 (1): 1-38.

Huang, J., and D. J. Kisgen. 2013. Gender and Corporate Finance: Are Male Executives Overconfident Relative to Female Executives? Journal of Financial Economics. Vol. 108 (3): 822-839.

Jensen, M. C., and W. H. Meckling. 1976. Theory of The Firm: Managerial Behavior, Agency Costs, and Ownership Structure. Journal of Financial Economics. Vol. 3: 305-360.

John, K., and L. W. Senbet. 1998. Corporate Governance and Board Effectiveness. Journal of Banking and Finance. Vol. 22 (4): 371-403.

Levi, M., K. Li, and F. Zhang. 2014. Director Gender and Mergers and Acquisitions. Journal of Corporate Finance. Vol. 28: 185-200.

Kang, E., D. K. Ding, and C. Chaeroenwong. 2010. Investor Reaction to Women Directors. Journal of Business Research. Vol. 63 (8): 888-894.

Krause, R., M. Semadeni, and A. A. Canella. 2014. CEO Duality: A Review and Research Agenda. Journal of Management. Vol. 40 (1): 256-286.

Kusumastuti, S., Supatmi, and P. Sastra. 2007. Pengaruh Board Diversity terhadap Nilai Perusahaan dalam Perspektif Corporate Governance. Jurnal Akuntansi dan Keuangan. Vol. 9 (2): 88-98.

Mardiyati, U. 2016. Pengaruh Frekuensi Rapat Dewan Direktur dan Jumlah Direktur Perempuan terhadap Kinerja Perusahaan. Ekuitas: Jurnal Ekonomi dan Keuangan. Vol. 20 (2): 172-187.

McNichols, M. F. 2002. Discussion of The Quality of Accruals and Earnings: The Role of Accrual Estimation Errors. The Accounting Review. Vol. 77 (4): 61-69.

Mishra, D. R. 2014. The Dark Side of CEO Ability: CEO General Managerial Skills and Cost of Equity Capital. Journal of Corporate Finance. Vol. 29: 390-409.

Srinidhi, B., F. A. Gul, and J. Tsui. 2011. Female commissioners and Earnings Quality. Contemporary Accounting Research. Vol. 28 (5): 1610-1644.

Upadhyay, A. D., R. Bhargava, and S. D. Faircloth. 2014. Board Structure and Role of Monitoring Committees. Journal of Business Research. Vol. 67 (7): 1486-1492. 
Watts, R. L., and Zimmerman, J. L. 1986. Positive Accounting Theory. New Jersey: Prentice Hall. 
The Indonesian Journal of Accounting Research - Jan, Vol. 21, No.2 , 2018

intentionally blank 